\title{
The Statement of Cash Flows in the Romanian Accounting Practice
}

\author{
Manea Marinela-Daniela \\ m_manea7@yahoo.com \\ Valahia University of Targoviste, Romania
}

\begin{abstract}
According to the Romanian legislation in force, medium and large entities as well as publicinterest entities present the statement of cash flows as part of the financial statements set. This paper aims to map out the way in which cash flows are prepared by the two methods know in the practice - direct and indirect.
\end{abstract}

Keywords: cash flow statement, operating activities, financing activities, investing activities.

JEL classification: M41

\section{Introduction}

As a tool for assessing an entity's performance, the cash flow statement has grown over the last 20 to 30 years, with the awareness of the information limits of the results account. Cases of entities have been identified that, although they have made profit, have not been able to dispose of sufficient liquidity to pay various debts such as corporate income tax, staff salaries or dividends to shareholders, etc. In these situations, although there was a good management of profit-generating income and expenses, management has mismanaged treasury flows, failing to acquire liquidity as needed for payment. Thus, current or potential shareholders are becoming increasingly interested in information about the entity's ability to pay future dividends than the current profit.

Informations concerning the cash flows of an entity are useful to provide sufficient elements for assessing the entity's ability to generate cash and cash equivalents to users of financial statements. When used in conjunction with the rest of the financial statements, the cash flow statement provides information that allows users to evaluate changes in an entity's net assets, its financial structure (including its liquidity and solvency), and the entity's ability to influence value and timing of treasury flows. In addition, past information on cash flows is often used as indicators of value, time placement and certainty of future cash flows.

Regardless of the nature of the entity's activities and whether the cash can be considered as the product of the entity (as may be the case for a financial institution) they need cash to carry out their activities, pay their obligations and maintain their profitability. And although the presentation of the cash flow situation is necessary for all entities, the Romanian regulator [1] considers useful only the elaboration of the situation of cash - flows by medium and large entities as well as those of public interest.

\section{Literature review}

The Statement of cash flows presents the receipts and payments made by an entity over the course of one year, the scene construction being based on the concepts of treasury (cash and cash equivalents) and the flows of Treasury (cash-flows). Through the entity's Treasury we understand the set of liquidity and liquidity equivalents available to the entity. Liquidities (cash) are delimited in cash and demand deposits. Cash equivalents represent short-term placements with a high degree of liquidity that can easily be converted into amounts of money. In the category of liquidity equivalents, we refer to term deposits, deposit certificates and treasury bills issued by 
the government, all with a maturity of up to three months, all those financial resources held to meet short-term commitments and not for investments or other purposes.

Structurally, the cash flow statement reports flows/cash flows of operating, investing and financing activities.

The amount of cash flows arising from operating activities is a key indicator of the extent to which the entity's activities generated sufficient cash flows to repay the loans, to maintain the entity's ability to operate, to pay dividends and to make new investments without resorting to external sources of funding. These cash flows generally arise from the entity's main incomegenerating activities. Typically, operating cash flows arise principally from transactions and other events that result in determining the profit or loss.

Examples of cash flows from operating activities may be (art. 455 of THE OMFP No. 1.802/2014):

$\checkmark$ cash receipts from the sale of goods and the provision of services;

$\checkmark$ cash receipts from royalties, fees, commissions and other income;

$\checkmark$ cash payments geared towards suppliers of goods and service providers;

$\checkmark$ cash payments made to and on behalf of employees;

$\checkmark$ cash payments or profits tax refunds, unless they may be specifically linked to investment and financing activities;

$\checkmark$ cash receipts/cash payments of an insurance premium and claims insurance, annuities and other benefits related to insurance policies;

$\checkmark$ cash receipts and payments from contracts concluded for placement or trading.

Some transactions, such as selling a component of an installation, can generate a recognized gain or loss in the result of the current period. Cash flows related to this type of transaction are cash flows from investment activities. However, cash payments for the generation/acquisition of assets held for lease to others are cash flows from operating activities. Cash receipts from the rental and subsequent sale of these assets are also cash flows from operating activities (art No. 454 paragraph 2 OMFP No. 1.802/2014). In addition, both paid interest and received interest/dividends can be classified as operating cash flows because they are included in the profit or loss determining process.

Separate presentation of cash flows from investing activities shows the extent to which the expenses incurred served to obtain resources intended to generate future revenues and cash flows. Examples of cash flows from investing activities may be (Article 456 of OMFP No 1.802 / 2014):

$\checkmark$ cash payments for the purchase of tangible, intangible and other fixed assets. Such payments shall include those which relate to the capitalised development costs and the construction, in its own direction, of tangible assets;

$\checkmark$ cash receipts from the sale of tangible, intangible and other immobilised assets;

$\checkmark$ cash payments for the acquisition of equity or debt instruments of other entities and interests in joint ventures (other than payments for instruments considered to be cash equivalents or for those held for placement or trading);

$\checkmark$ cash receipts from the sale of equity or debt instruments of other entities and from the sale of interests in joint ventures (other than receipts for instruments deemed to be equivalent to cash and for those kept for placement or trading);

$\checkmark$ cash advances and loans granted to other parties (other than advances and loans granted by a financial institution);

$\checkmark$ cash receipts from repayment of advances and loans granted to other parties (other than advances and loans of a financial institution).

Separate presentation of cash flows generated from financing activities is important because it is useful to predict the entity's financing requirements for future cash flows.

Examples of cash flows from the activities of funding can be (art. 457 of OMFP No. 1.802/2014):

$\checkmark$ cash receipts generated from the issue of shares or other equity instruments; 
$\checkmark$ cash payments made to owners to acquire or redeem the entity's shares;

$\checkmark$ cash receipts from the issue of debt securities, loans, trade effects, bonds, mortgages and other short or long-term loans;

$\checkmark$ cash refunds of borrowed amounts;

$\checkmark$ cash payments made by the lessee to reduce the existing debt under a finance lease.

Also, paid interest and received interest/dividends can be classified as treasury flows from financing and from investments because they represent costs of attracting sources of financing or return on investment (art . 459, para. 2 OMFP No. 1.802/2014).

In addition, although the unrealized gains and losses arising from exchange rate fluctuations are not cash flows, the effect of exchange rate fluctuations on cash and cash equivalents held or denominated in foreign currencies is reported in the cash flow statement to reconcile cash and cash equivalents at the beginning and end of the period. This value is presented separately from cash flows arising from operating, investing and financing activities and includes, where appropriate, the differences that would have arisen if those cash flows were reported at the end-of-period exchange rate (art. 458 OMFP no 1.802/2014).

\section{Reporting of cash flows from operating activities}

The Romanian regulations in force have taken over the requirements of IAS 7 "Statement of cash Flows" for the presentation of cash flows from operating activities, but using with preference the direct method. The present paper presented booth the methods: direct and indirect. If, according to the direct method, the flows are derived from the main classes of gross cash payments and receipts, in the indirect method [2] the profit or loss is adjusted with the effects of non-monetary transactions, deferrals or commitments of payments or cash receipts from exploitation, past or future, and items of income or expense associated with cash flows from investing or financing.

We present below in Tables no. 1 and 2 the structure of treasury flows according to the indirect and direct method.

Table No. 1 Statement of cash flows according to the indirect method

\begin{tabular}{|l|l|}
\hline \multicolumn{1}{|c|}{ Specification } & Amounts \\
\hline Gross profit before tax & \\
\hline Eliminating non-treasury revenue and expenses: & \\
\hline + Expenses with depreciation of fixed assets & \\
\hline + Current assets value adjustments expenditures & \\
\hline - Provisions income & \\
\hline Non-operating income and expenses elimination: & \\
\hline + Tangible assets sale losses & \\
\hline - Tangible assets sale gains & \\
\hline + Funding related interest expense & \\
\hline - Investments interest income & \\
\hline = Operating result before the change in working capital requirement & \\
\hline - Stock change & \\
\hline - Receivables variation & \\
\hline - Operating upfront expenditure variation & \\
\hline + Operating debts variation & \\
\hline -Paid profit tax & \\
\hline = Net cash from operating activities (I) & \\
\hline + Proceeds from tangible assets sales & \\
\hline - Provider payments for property, plant or equipment & \\
\hline - Long-term loans payments & \\
\hline + Repayment Receipts from long-term loans & \\
\hline
\end{tabular}




\section{+ Interest receipts on loans granted}

= Investment activity net cash (II)

-Cash payments from capital contributions reimbursement

+ Short term credit receipts

- Interest payments

$=$ Financing activity net cash (III)

IV Net increase in cash $(I+I I+I I I)$

$V$ Cash at the beginning of the period

VI Cash at the end-period $(+/-I V+V)$

Table No. 2 Situation of operating cash flows according to the direct method

\begin{tabular}{|l|c|}
\hline \multicolumn{1}{|c|}{ Specification } & Amounts \\
\hline Customer receipts & \\
\hline + Fees, commissions receipts & \\
\hline + Operating subsidies receipts & \\
\hline -Services and stock suppliers payments & \\
\hline - Employee payments & \\
\hline -Social contributions payments & \\
\hline -VAT payments & \\
\hline -Operating lease rents payments & \\
\hline -Corporate tax payments & \\
\hline = Operational activity cash & \\
\hline
\end{tabular}

\section{Cash flow statement elaboration by direct and indirect method}

In order to reflect the cash flow situation according to the direct method, we consider the following case study for ALFA enterprise, which during the year $\mathrm{N}$ showed in the accounts the following receipts and payments (in lei):

\begin{tabular}{|l|c|}
\hline Customer receipts & 3.680 .000 \\
\hline VAT payments & 344.000 \\
\hline Operating subsidies proceeds & 280.000 \\
\hline Employee payments & 1.520 .000 \\
\hline Payments from the repayment of bank loans & 656.000 \\
\hline Fees and commissions receipts & 80.000 \\
\hline Receipts from issue of shares & 1.760 .000 \\
\hline Financial lease rents payments & 344.000 \\
\hline Short-term financial investments sale proceeds & 72.000 \\
\hline Financial fixed assets sale proceeds & 104.000 \\
\hline Interest payments & 320.000 \\
\hline Dividend payments & 128.000 \\
\hline Corporate tax payments & 264.000 \\
\hline Receipts from new bond issues & 336.000 \\
\hline Received bank credits receipts & 688.000 \\
\hline Social contribution payments & 240.000 \\
\hline Proceeds from tangible assets sale & 480.000 \\
\hline Interest receipts & 224.000 \\
\hline Asset provider payments & 720.000 \\
\hline Dividend Receipts & 600.000 \\
\hline Operating lease rents payments & 160.000 \\
\hline
\end{tabular}


Investment grants receipts

Acquisition of short-term financial investment payments

880.000

Inventory and service providers payments

64.000

480.000

At the beginning of the year the cash and cash equivalents amounted to 960,000 lei and at the end of the year they amounted to 5,096,000 lei. The effect of foreign currency exchange rate variations was $+192,000$ lei. It is required to prepare the cash flow statement according to OMFP no. 1.802/2014, knowing that direct method is used to determine net operating flow.

Table No. 3 Statement of cash flows according to the direct method

Statement of Cash Flows

Treasury cash flows from operating activities (direct method)

Receipts from customers

Fees and commissions receipts

3.680 .000

Operating subsidies receipts

Inventory and service providers payments

$+80.000$

Employee payments

$+280.000$

Social contribution payments

$-480.000$

$-1.520 .000$

$-240.000$

VAT payments

$-344.000$

Operating lease rents payments

$-160.000$

Corporate tax payments

I. Net cash from operating activities

Treasury cash flows from investment activities

Proceeds from tangible assets sale

Short-term financial investments sale proceeds

$-264.000$

Financial fixed assets sale proceeds

Interest receipts

Dividend receipts

$+1.032 .000$

Investment grants receipts

Payments to asset providers

Short-term financial investments sale proceeds

II.Net cash from investing activities

Treasury flows from financing activities

Receipts from share issues

Receipts from new bond issues

Receipts from bank credits received

Payments from bank loans repayments

Interest payments

Dividend payments

Financial lease rents payments

III. Net cash from financing activities

IV. Net increase in treasury and treasury equivalents (I+II+III)

V. Treasury and treasury equivalents at the beginning of the period

VI. Foreign currency exchange rate variations effect

$+480.000$

$+72.000$

$+104.000$

$+224.000$

$+600.000$

$+880.000$

$-720.000$

$-64.000$

$+1.576 .000$

VII. Treasury and treasury equivalents at the end of the period

$(+/-I V+V+/-V I)$

$+1.760 .000$

$+336.000$

$+688.000$

$-656.000$

$-320.000$

$-128.000$

$-344.000$

$+1.336 .000$

$+3.944 .000$

$+960.000$

$+192.000$

$+5.096 .000$ 
In order to develop the cash flow situation of the BETA entity, at the 31.12.N the following information is known, in RON:

\begin{tabular}{|c|c|}
\hline Gross profit & 4.320 .000 \\
\hline Customers receipts & 720.000 \\
\hline Depreciation of fixed assets expenses & 160.000 \\
\hline Paid corporate tax & 192.000 \\
\hline Cash payments from capital contributions reimbursement & 320.000 \\
\hline Stocks at the end of the year & 240.000 \\
\hline Provisions income & 128.000 \\
\hline Tangible assets sale losses & 256.000 \\
\hline $\begin{array}{l}\text { Operating payables at the end of the year (excluding corporate } \\
\text { income tax) }\end{array}$ & 2.640 .000 \\
\hline Long-term loans payments & 640.000 \\
\hline Early operating income at the beginning of the year & 160.000 \\
\hline Received short-term loans receipts & 400.000 \\
\hline Proceeds from the tangible assets sale & 152.000 \\
\hline Stocks at the beginning of the year & 480.000 \\
\hline Upfront expenses at the end of the year & 128.000 \\
\hline Receipts from repayment of long-term loans & 80.000 \\
\hline Operating claims at the end of the year & 2.240 .000 \\
\hline Payments to asset providers & 528.000 \\
\hline Interest income from investments & 136.000 \\
\hline Upfront expenses at the beginning of the year & 40.000 \\
\hline Operating claims at the beginning of the year & 1.360 .000 \\
\hline Proceeds from tangible assets sale & 528.000 \\
\hline Funding related interest expense & 160.000 \\
\hline $\begin{array}{l}\text { Operating liabilities at the beginning of the year (excluding corporate } \\
\text { tax) }\end{array}$ & 3.680 .000 \\
\hline Interest payments & 160.000 \\
\hline Turnover & 1.600 .000 \\
\hline Operation revenues at the end of the year & 184.000 \\
\hline Current assets value adjustments expenditures & 8.000 \\
\hline Corporate tax expense & 400.000 \\
\hline Interest receipts on granted loans & 136.000 \\
\hline Employee payments & 960.000 \\
\hline
\end{tabular}

Treasury and treasury equivalents at the beginning of the year were 640,000 lei and at the end of the year 1,936,000 lei. It is required to prepare the cash flow statement under IAS 7, knowing that indirect method is used to determine net operating flow.

Table No. 4 Statement of cash flows according to the indirect method

\section{Statement of Cash Flows}

Treasury flows from operating activities (indirect method)

Profit before tax (gross profit)

Elimination of revenue and expenses with no effect on the treasury:

+ Expenses with fixed assets depreciation

+ Current assets value adjustments expenditures

\begin{tabular}{|c|c|}
\hline 4.320 .000 \\
\\
\hline+160.000 \\
\hline
\end{tabular}


International Conference "Risk in Contemporary Economy" ISSN-L 2067-0532 ISSN online 2344-5386

$X^{\text {th }}$ Edition, 2019, Galati, Romania,

"Dunarea de Jos" University of Galati, Romania - Faculty of Economics and Business Administration

\begin{tabular}{|c|c|}
\hline - Provisions income & -128.000 \\
\hline \multicolumn{2}{|l|}{ Elimination of non-related exploitation income and expenses } \\
\hline+ Tangible assets sale losses & +256.000 \\
\hline - Proceeds from the tangible assets sale & -528.000 \\
\hline+ Funding related interest expense & +160.000 \\
\hline - Investments interest income & -136.000 \\
\hline $\begin{array}{l}\text { Operating result before deducting the change in operating } \\
\text { capital requirement }\end{array}$ & +4.112 .000 \\
\hline$(-)$ Stock change $240.000-480.000=-240.000$ & +240.000 \\
\hline$(-)$ Receivables variation $2.240 .000-1.360 .000=880.000$ & -880.000 \\
\hline$(-)$ Variation in upfront operating expenses $128.000-40.000=88.000$ & -88.000 \\
\hline $\begin{array}{l}(+) \text { Change in operating liabilities (excluding corporate tax)2.640.000 - } \\
3.680 .000=-1.040 .000\end{array}$ & -1.040 .000 \\
\hline$(+)$ Variaton of operation upfront revenue $184.000-160.000=24.000$ & +24.000 \\
\hline (-) Paid corporate tax & -192.000 \\
\hline I. Net cash from operating activities & +2.176 .000 \\
\hline \multicolumn{2}{|l|}{ Treasury flows from investment activities } \\
\hline Tangible assets sale proceeds & +152.000 \\
\hline Asset providers payments & -528.000 \\
\hline Payments from long-term loans & -640.000 \\
\hline Receipts from the of long-term loans repayment & +80.000 \\
\hline Interest receipts on granted loans & +136.00 \\
\hline II. Net cash from investing activities & -800.000 \\
\hline \multicolumn{2}{|l|}{ Treasury flows from financing activities } \\
\hline Cash payments from capital contributions reimbursement & -320.000 \\
\hline Receipts from received short term credits & +400.000 \\
\hline Interest payments & -160.000 \\
\hline III. Net cash from financing activities & -80.000 \\
\hline IV. Net increase in treasury and treasury equivalents (I+II+III) & +1.296 .000 \\
\hline $\begin{array}{l}\text { V. Treasury and treasury equivalents at the beginning of the } \\
\text { period }\end{array}$ & +640.000 \\
\hline $\begin{array}{l}\text { VI. Treasury and treasury equivalents at the end of the period } \\
(+/-I V+V)\end{array}$ & +1.936 .000 \\
\hline
\end{tabular}

\section{Conclusions}

The cash flow statement provides a snapshot of the entity's financial structure, showing important information about operating cash, investments and financing that cannot be obtained either from the balance sheet or the profit and loss account. The structure of the cash flow table also provides additional information to users of financial statements to assess an entity's assets, liabilities and equity changes.

The paper has proposed a graded completion of the cash flow statement structure, the reporting of operating cash flows, and the direct and indirect cash flow statement to familiarize professional accountants and account users with this component of the annual financial statements.

\section{References}

[1,] IAS 7 The cash - flow statements, Annual Improvements to IFRS Standards 2015 - 2017 Cycle;

[2] OMFP no. 1802/2014 for the approval of the Accounting Regulations on the individual annual financial statements and the consolidated annual financial statements, Official Gazette no. 963/2014. 